No 4078

Studia nad Autorytaryzmem i Totalitaryzmem 43, nr 4 Wrocław 2021

https://doi.org/10.19195/2300-7249.43.4.34

\author{
KAROLINA PASOŃ \\ ORCID: 0000-0002-0582-3706 \\ Uniwersytet Wrocławski \\ karolina.pason@uwr.edu.pl
}

\title{
Sytuacja prawna ofiary przestępstwa w postępowaniu wykonawczym w perspektywie sprawiedliwości naprawczej
}

Slowa kluczowe: instytucje totalne, sprawiedliwość naprawcza, pokrzywdzony, prawo karne, postępowanie wykonawcze.

\section{THE LEGAL SITUATION OF A CRIME VICTIM IN EXECUTIVE PROCEEDINGS IN THE PERSPECTIVE OF RESTORATIVE JUSTICE}

\begin{abstract}
The article is devoted to the legal situation of a crime victim in the course of executive penal proceedings. The starting point for the considerations was the statement that Goffman's concept of total institutions and the resulting negative consequences, such as the effects of deculturation or deprivation affecting inmates, are still valid in relation to Polish penitentiary units. It is considered that restorative justice can be an effective instrument for the transition from a total institution to its negation, that is, a permeable institution, especially insofar as it promotes tools for victim and community activation in criminal proceedings. Therefore, the situation of the victim in the current model of executive proceedings was analyzed from the perspective of the possibility of implementing the idea of restorative justice. The subject matter of the article is not limited only to a synthesis of the victim's rights under the current Executive Penal Code. The provisions normalizing the rights of the victim were analyzed in the context of the whole Code regulation and with reference to the earlier stages of criminal proceedings. In this way a complete and actual picture of the victim's situation at this stage of criminal proceedings was presented, which was then compared with the standard of restorative justice. The critical analysis made it possible to identify the shortcomings in the current regulation of the victim's legal situation and to outline the direction in which the legislator should proceed in order to achieve the standard of restorative justice, which will make it possible to increase the permeability of penitentiary units and thus minimize their total character.
\end{abstract}

Keywords: total institutions, restorative justice, victim, criminal law, enforcement proceedings. 


\section{Wstęp}

Mimo upływu przeszło 60 lat od wydania Asylums ${ }^{1}$ współcześnie wciąż aktualne i zasadne wydaje się odnoszenie Goffmanowskiej koncepcji instytucji totalnych do polskich jednostek penitencjarnych. Jest to o tyle istotne, że zaobserwowane przez Ervinga Goffmana negatywne konsekwencje wynikające z funkcjonowania przez dłuższy czas struktury instytucji totalnej, takie jak efekty dyskulturacji ${ }^{2}$ czy deprywacji ${ }^{3}$, nadal dostrzegalne są $\mathrm{w}$ praktyce penitencjarnej i niewątpliwie stanowią ważne argumenty przemawiające przeciwko długoterminowej karze pozbawienia wolności. Nadużyciem byłoby jednak stosowanie ich na zasadzie wnioskowania a minore ad maius, przeciwko jednostkom penitencjarnym jako takim, zwłaszcza że na obecnym etapie rozwoju cywilizacyjnego należy porzucić myśl o całkowitej likwidacji więzień. Nic nie stoi jednak na przeszkodzie, by stale dążyć do ewolucji i unowocześniania jednostek penitencjarnych, nie tylko pod kątem technologicznym.

W tym kontekście warto odnotować, że za przeciwieństwo instytucji totalnej uznaje się typ idealny instytucji przenikalnej (ang. permeable institution). Charakteryzuje się ona między innymi: krótkim pobytem mieszkańców i częstą zmianą personelu, przestrzenną bliskością ze światem zewnętrznym oraz kontaktem z nim poprzez odwiedziny, telefony i Internet, transparentnością procedur, dobrowolnością przystępowania, możliwością zachowania własnej tożsamości z zewnątrz, rozmyciem podziału na pacjentów i obsługę oraz nieformalnością tych relacji ${ }^{4}$. Koncepcję instytucji przenikalnej można uznać — przynajmniej w pewnych aspektach — za wzór, do którego warto dążyć, zmieniając jednostki penitencjarne, zwłaszcza w aspekcie szeroko rozumianej bliskości ze światem zewnętrznym.

Wprawdzie w literaturze przedmiotu niejednokrotnie poruszano zagadnienie udziału społeczeństwa w postępowaniu karnym ${ }^{5}$, czego normatywnym wyrazem

${ }^{1}$ E. Goffman, Asylums. Essays on the Social Situation of Mental Patients and Other Inmates, Garden City 1961.

2 Termin wprowadzony przez R. Sommera w artykule Patients Who Grow Old in a Mental Hospital, „Geriatrics” 14, 1959, s. 586-587.

3 E. Goffman, Instytucje totalne. O pacjentach szpitali psychiatrycznych i mieszkańcach innych instytucji totalnych, Sopot 2011, s. 23 i 75.

4 A. Quirk, P. Lelliot, C. Seale, The Permeable Institution: An Ethnographic Study of Three Acute Psychiatric Wards in London, „Social Science \& Medicine” 63, 2006, cyt. za: Ł. Posłuszny, Instytucje totalne dzisiaj: stan badań, krytyka, rekonfiguracje, „Studia Socjologiczne” 4 (227), 2017, s. 130.

5 Zob. m.in. Z. Młynarczyk, Udział czynnika społecznego w postępowaniu karnym wykonawczym, „Ruch Prawniczy, Ekonomiczny i Socjologiczny” 1979, nr 3; K. Łapińska, M. Mańczuk, Udziat społeczeństwa $w$ polskim postępowaniu wykonawczym $-z$ uwzględnieniem wybranych regulacji państw europejskich, „Białostockie Studia Prawnicze” 2016, z. 21; K. Wieczorek, Udziat czynnika społecznego $w$ orzekaniu $w$ polskim i amerykańskim procesie karnym, Szczecin 2012; B. Janusz-Pohl, Zasada udziatu czynnika społecznego, [w:] System prawa karnego procesowego. Zasady procesu karnego, red. P. Wiliński, Warszawa 2014. 
na gruncie kodeksu karnego wykonawczego ${ }^{6}$ są przepisy rozdziału VII, to w praktyce wciąż niewiele zmieniło się w tym zakresie. W obecnym modelu sprawiedliwości retrybutywnej dominującą i zarazem centralną postacią postępowania karnego niezmiennie jest sprawca czynu zabronionego. Nils Christie przyczyn takiego stanu rzeczy upatruje w tym, że jako społeczeństwo nazbyt skoncentrowaliśmy się na przestępcy, czyniąc go obiektem badań, manipulacji i kontroli. W ocenie tego badacza dołożyliśmy wszelkich starań, by zredukować ofiarę do nicości, a przestępcę do rzeczy ${ }^{7}$. Być może wynika to stąd, że

Ponieważ sami boimy się przestępstw, nie bardzo umiemy postępować z ich ofiarami. Ofiary przypominają nam o naszej własnej kruchości i bezbronności, w ten sam sposób, w jaki osoby terminalnie chore przypominają nam o tym, że jesteśmy śmiertelni. Dlatego też często ignorujemy ofiary, lekceważymy ich opowieści i obarczamy je winą za to, co się wydarzyło. Czynimy je niewidzialnymi ${ }^{8}$.

W tak ukształtowanym systemie sprawiedliwości ofiara przestępstwa ,przegrywa” podwójnie. Po pierwsze dlatego, że cierpi fizycznie i psychicznie z powodu doznanej krzywdy lub szkody. Po drugie zaś dlatego, że zostaje pozbawiona głosu i udziału we własnej sprawie na rzecz państwa ${ }^{9}$.

Taki stan rzeczy ma miejsce również w ostatnim etapie postępowania karnego. Aktualnie brzmienie kodeksu karnego wykonawczego nie pozostawia wątpliwości, kto jest pierwszoplanowym bohaterem postępowania wykonawczego. Ustawodawca poświęca skazanemu w całości jeden z pierwszych rozdziałów kodeksu. Wyraża w nim podstawowe zasady, które jako że mają zastosowanie przy wykładni wszystkich przepisów kodeksu, chronią interes skazanego w toku całego postępowania wykonawczego. Oprócz zasady humanitaryzmu, poszanowania godności ludzkiej, zakazu tortur lub nieludzkiego albo poniżającego traktowania i karania ustawodawca konstytuuje w nim także zasadę podmiotowości skazanego, stanowiąc, że jest on podmiotem praw i obowiązków określonych w tym kodeksie. Taki stan rzeczy nie był dotychczas podważany, tym bardziej że na pierwszy rzut oka znajduje potwierdzenie w normatywnych celach wykonywania kary pozbawienia wolności. Wydawać by się mogło, że ustawodawca w przepisie art. $67 \S 1$ k.k.w. dostrzega wyłącznie osobę skazanego, skoro zadekretował, że wykonywanie kary pozbawienia wolności ma na celu wzbudzanie w nim woli współdziałania w kształtowaniu jego społecznie pożądanych postaw. Trzeba jednak mieć na uwadze, że jedną z tych społecznie pożądanych postaw jest odpowiedzialność, którą należałoby rozumieć jako obowiązek moralny lub prawny

${ }^{6}$ Ustawa z dnia 6 czerwca 1997 roku — Kodeks karny wykonawczy (tekst jedn. Dz.U. z 2021 r. poz. 53; dalej: k.k.w.).

7 N. Christie, Conflicts as Property, „The British Journal of Criminology” 17, 1977, nr 1, s. 5.

8 D. Van Ness, cyt. za: J. Llewellyn, R. Howse, Restorative Justice - A Conceptual Framework, [Ottawa] 1998, s. 24.

9 N. Christie, op. cit., s. 7. 
odpowiadania za swoje czyny i ponoszenia ich konsekwencji ${ }^{10}$. Nie ulega przy tym wątpliwości, że na etapie postępowania karnego wykonawczego obowiązek ten powinien być odczytywany przede wszystkim jako powinność naprawienia szkody lub zadośćuczynienia za krzywdzę wyrządzoną przestępstwem.

Takie pogłębione rozumienie celu kary pozbawienia wolności, o którym mowa w art. $67 \S 1$ k.k.w., otwiera drogę do rozważań nad uczestnictwem i sytuacją prawną osoby pokrzywdzonej przestępstwem w postępowaniu karnym wykonawczym. Zagadnienie to, być może nieco marginalizowane w przeszłości, $\mathrm{w}$ ocenie autorki w niedługiej przyszłości nabierze istotnego znaczenia, również w kontekście zwiększania przenikalności jednostek penitencjarnych rozumianej jako wzajemne oddziaływanie na siebie wewnątrzinstytucjonalnych standardów społecznych oraz standardów zewnętrznych, skutkujące tendencją do minimalizowania różnic ${ }^{11}$. W ustawodawstwie europejskim i unijnym coraz więcej uwagi poświęca się bowiem sytuacji prawnej ofiary przestępstwa w postępowaniu karnym, w szczególności w perspektywie sprawiedliwości naprawczej, która w ostatnich latach stała się jednym z najpopularniejszych tematów w światowej debacie dotyczącej współczesnej polityki kryminalnej.

Pierwszym znaczącym wyrazem tej tendencji było przyjęcie przez Parlament Europejski i Radę Unii Europejskiej w dniu 25 października 2012 roku dyrektywy 2012/29/UE ustanawiającej normy minimalne w zakresie praw, wsparcia i ochrony ofiar przestępstw oraz zastępującej decyzję ramową Rady 2001/220/WSiSW (dalej: dyrektywa). Dyrektywa posługuje się jednak ogólnym określeniem „,postępowanie karne", a w sposób jednoznaczny odnosi się wyłącznie do postępowań przygotowawczego i sądowego. Analiza całokształtu regulacji pozwala sądzić, że ten akt prawny dotyczy raczej postepowania karnego przed wydaniem wyro$\mathrm{ku}$ (pre-sentencing level). Wątpliwości nie pozostawia natomiast rekomendacja nr CM/Rec(2018) Komitetu Ministrów Rady Europy dla państw członkowskich dotycząca sprawiedliwości naprawczej w sprawach karnych przyjęta przez Komitet Ministrów 3 października 2018 roku na 1326. posiedzeniu Przedstawicieli Ministrów (dalej: rekomendacja). W punkcie 6 stanowi ona wprost, że sprawiedliwość naprawcza może być stosowana na każdym etapie postępowania karnego, $\mathrm{w}$ tym mającym miejsce po wydaniu lub odbyciu wyroku (post-sentencing level).

Obie te regulacje stanowia normatywny wyraz tendencji do zwiększenia uprawnień osób pokrzywdzonych przestępstwem w postępowaniu karnym na wszystkich jego etapach. Mając jednocześnie na względzie, że dotychczas w literaturze naukowej zdecydowanie więcej uwagi poświęcono uprawnieniom pokrzywdzonego $\mathrm{w}$ postępowaniu przygotowawczym i sądowym ${ }^{12}$, zasadne

10 T. Kalisz, A. Kwieciński, Cele izolacji penitencjarnej w perspektywie odrzucenia idei przymusowej resocjalizacji, „Przegląd Prawa i Administracji” 95, 2013, s. 125.

11 E. Goffman, Instytucje totalne..., s. 121.

12 Zob. m.in. E. Bieńkowska, Pokrzywdzony w świetle najnowszych nowelizacji przepisów prawa karnego, „Prokuratura i Prawo” 2014, nr 3; eadem, Ofiary przestępstw w postepowaniu kar- 
wydaje się rozważanie sytuacji prawnej ofiary w postępowaniu wykonawczym W perspektywie sprawiedliwości naprawczej. Warto przy tym zwrócić uwagę, że sprawiedliwość naprawcza, dzięki propagowanym wartościom i narzędziom służącym zwiększeniu aktywności ofiary i społeczności lokalnej w szeroko rozumianym postępowaniu karnym, przyczynia się do wzrostu przenikalności jednostek penitencjarnych, znacząco minimalizując ich totalny charakter.

\section{Pokrzywdzony a ofiara w perspektywie sprawiedliwości naprawczej}

Sprawiedliwość naprawcza - ujmując rzecz najogólniej i stosując zarazem terminologię wprowadzoną przez Nilsa Christie — ma polegać na zwróceniu konfliktu zawłaszczonego przez państwo, organy ścigania oraz prawników jego pierwotnym właścicielom, czyli ofierze i sprawcy ${ }^{13}$. Precyzując tę definicję, Jim Consedine wyjaśnia, że

Sprawiedliwość naprawcza jest filozofią dającą nam szansę na wprowadzenie wartości, które czynią ludzi wielkimi - prawdziwa sprawiedliwość opiera się na przeprosinach, współczuciu, uzdrowieniu, litości, pojednaniu, wybaczeniu, a tam, gdzie to konieczne, na sankcjach. Oferuje ona proces, w którym wszyscy dotknięci zachowaniem przestępczym — zarówno ofiary, przestępcy, ich rodziny, jak i szersza społeczność — mogą mieć udział w rozwiązaniu kwestii będących skutkiem przestępstwa ${ }^{14}$.

W tym kontekście Howard Zehr przekonuje: „Zamiast definiować sprawiedliwość jako karę, zdefiniujmy sprawiedliwość jako naprawę. Jeśli przestępstwo jest szkodą, niech prawo naprawi szkody i promuje uzdrowienie"15.

W ten sposób rozumiana sprawiedliwość naprawcza na gruncie normatywnym definiowana jest jako wszelkie procedury, dzięki którym ofiara oraz sprawca mają możliwość, pod warunkiem wyrażenia przez nich na to dobrowolnej zgody, czynnego udziału w rozwiązaniu kwestii będących wynikiem przestępstwa przy pomocy bezstronnej strony trzeciej ${ }^{16}$. Twórcy rekomendacji, definiując sprawiedliwość naprawczą, podkreślili dodatkowo rolę facylitatora, stwierdzając, że ma

nym - nowe standardy Unii Europejskiej, „Państwo i Prawo” 2014, nr 4; eadem, Uprawnienia pokrzywdzonego w ujęciu nowych projektów nowelizacji prawa karnego, „Prokuratura i Prawo” 2014, nr 11-12; K. Dudka, G. Artymiak, Sytuacja pokrzywdzonego w procesie karnym ze szczególnym uwzględnieniem roli oskarżyciela posiłkowego i powoda cywilnego, Warszawa 2012; Pokrzywdzony jako uczestnik postępowań represyjnych. Czwarty wierzchołek trójkąta?, red. P. Czernecki, A. Światłowski, Warszawa 2021.

13 Zob. N. Christie, op. cit.

14 J. Consedine, Sprawiedliwość naprawcza. Przywrócenie ładu społecznego, Warszawa 2004, s. 220 .

15 H. Zehr, cyt. za: ibidem, s. 91.

16 Art. 1 lit. d dyrektywy. 
się on zająć procesem, w którym umożliwia się osobom pokrzywdzonym przez przestępstwo oraz tym odpowiedzialnym za pokrzywdzenie, jeżeli dobrowolnie wyrażają zgodę, aby z pomocą przeszkolonej i bezstronnej osoby trzeciej (facylitatora) mogli aktywnie uczestniczyć w rozwiązaniu sprawy powstałej w konsekwencji popelnienia tego przestępstwa ${ }^{17}$.

Niezależnie od tego, jak definiujemy sprawiedliwość naprawczą, w każdym przypadku fundamentalne jest dostrzeżenie roli i sytuacji prawnej osoby pokrzywdzonej przestępstwem oraz osoby odpowiedzialnej za to pokrzywdzenie. Mając jednak na uwadze temat niniejszego opracowania, dalsze rozważania zostaną poświęcone wyłącznie ofierze przestępstwa.

Poprzedzając jednak kolejne uwagi, w pierwszej kolejności należy wyjaśnić, że w tytule artykułu celowo użyto określenia „ofiara” zamiast „pokrzywdzony”. Wynika to z faktu, że zarówno twórcy naukowych, jak i normatywnych definicji sprawiedliwości naprawczej stosują zamiennie określenia „ofiara” lub „osoba pokrzywdzona przestępstwem” w miejsce terminu ,pokrzywdzony”. W ten sposób zachowują one w skali światowej uniwersalne znaczenie, którego nie można utożsamiać z definicjami obowiązującymi w porządkach krajowych, na przykład $\mathrm{z}$ definicją pokrzywdzonego uregulowaną $\mathrm{w}$ przepisie art. 49 kodeksu postępowania karnego ${ }^{18}$. Do rozstrzygnięcia pozostaje więc kwestia, w jakiej relacji pozostają z sobą oba wskazane określenia.

Na gruncie dyrektywy przez ofiarę należy rozumieć zarówno osobę fizyczną, która doznała szkody, w tym krzywdy fizycznej, psychicznej, moralnej lub emocjonalnej albo straty majątkowej, bezpośrednio spowodowanej przestępstwem, jak i członków rodziny osoby, której śmierć była bezpośrednim skutkiem przestępstwa, jeżeli doznali oni szkody w wyniku śmierci tej osoby. Przy tym przez członków rodziny rozumie się małżonka, osobę pozostającą z ofiarą, w sposób trwały i ciągły, w bliskim pożyciu we wspólnym gospodarstwie domowym, krewnych w linii prostej, rodzeństwo oraz osoby pozostające na utrzymaniu ofiary. $Z$ kolei rekomendacja nie zawiera wprawdzie autonomicznej definicji ofiary, lecz na wstępie odwołuje się wprost między innymi do dyrektywy, umożliwiając odpowiednie stosowanie przytoczonego właśnie wyjaśnienia tego terminu także na gruncie tego aktu prawnego. Warto jednak podkreślić, że rekomendacja w wielu miejscach zaznacza, że „dotknięte przestępstwem” mogą być również inne osoby aniżeli ofiara, a nawet lokalne społeczności, łącznie określane mianem „uczestników procesu sprawiedliwości naprawczej”, którzy także winni brać udział w określaniu i naprawianiu krzywd wyrządzonych przestępstwem.

Natomiast pokrzywdzonym w polskiej procedurze karnej jest wyłącznie osoba fizyczna lub prawna, której dobro prawne zostało bezpośrednio naruszone

17 Rozdział II ust. 3 rekomendacji.

18 Ustawa z dnia 6 czerwca 1997 roku - Kodeks postępowania karnego (tekst jedn. Dz.U. z 2021 r. poz. 534; dalej: k.p.k.). 
lub zagrożone przez przestępstwo. Pokrzywdzonym mogą być też niemająca osobowości prawnej instytucja państwowa lub samorządowa, jak również inna jednostka organizacyjna, której odrębne przepisy przyznają zdolność prawną. Za pokrzywdzonego uważa się także zakład ubezpieczeń w zakresie, w jakim pokrył szkodę wyrządzoną przestępstwem lub jest zobowiązany do jej pokrycia. W celu wyznaczenia zakresu desygnatów tego pojęcia należy uwzględnić, że o ile przytoczona właśnie definicja ofiary kładzie zdecydowany nacisk na faktyczne doznanie szkody, w tym krzywdy fizycznej, psychicznej, moralnej lub emocjonalnej albo straty majątkowej, o tyle definicja pokrzywdzonego ma przede wszystkim charakter materialnoprawny ${ }^{19}$. Oznacza to, że na gruncie kodeksu postępowania karnego o uzyskaniu statusu pokrzywdzonego nie przesądza poniesienie przez osobę rzeczywistego (a więc niewyimaginowanego) uszczerbku fizycznego lub psychicznego, straty materialnej lub znaczącego naruszenia podstawowych praw, lecz zestaw ustawowych znamion czynu zabronionego będącego przedmiotem postępowania oraz czynów współukaranych. W celu określenia kręgu osób pokrzywdzonych nie jest co do zasady konieczne stwierdzenie faktycznego uszczerbku fizycznego lub psychicznego, chyba że stanowić będzie skutek czynu zabronionego jako jedno ze znamion strony przedmiotowej, lecz przede wszystkim ustalenie naruszenia normy prawa karnego materialnego, wskazanie przedmiotu i zakresu tej normy oraz odnalezienie związku między znamionami czynu a zagrożeniem dobra prawnego konkretnego podmiotu. Dodatkowo sposób sformułowania art. 49 k.p.k. wymaga, aby dobro prawne zostało naruszone lub zagrożone w sposób bezpośredni, a więc taki, w którym między czynem zawierającym znamiona przestępstwa a naruszonym lub zagrożonym dobrem danego podmiotu nie ma ogniw pośrednich.

Przy tak formalnym ujęciu definicji pokrzywdzonego pozytywnie należy ocenić wyrażenie przez Sąd Najwyższy zapatrywania, że o „pokrzywdzeniu” nie zawsze decyduje wyłącznie opis czynu ani przyjęta kwalifikacja prawa, albowiem niejednokrotnie dochodzi do sytuacji, gdy niektóre przepisy zostają pominięte $\mathrm{w}$ kwalifikacji prawnej, ponieważ stanowią element czynu ciągłego lub zostają wyłączone $\mathrm{z}$ uwagi na zaistnienie pozornego zbiegu przepisów bądź stanowią czyn współukarany uprzednio lub następczo. W takich przypadkach przyjęta kwalifikacja prawa nie może przesądzać o statusie pokrzywdzonego ${ }^{20}$. Zarazem jednak sądy bardzo ściśle traktują przesłankę bezpośredniości naruszenia lub narażenia na naruszenie dobra prawnego. $Z$ tej przyczyny konsekwentnie odmawiają uznania za pokrzywdzonych w rozumieniu art. 49 k.p.k. rodziców oraz małżonka zabitej osoby. Sąd Najwyższy staje na stanowisku, że

19 M. Cieślak, Polska procedura karna, Warszawa 1971, s. 37.

20 Zob. wyrok SN z dnia 17 lutego 2010 roku, sygn. III KK 292/09, Legalis nr 364370; uchwała SN z dnia 21 grudnia 1999 roku, sygn. I KZP 43/99, Legalis nr 45347; uchwała SN z dnia 15 września 1999 roku, sygn. I KZP 26/99, Legalis nr 44490. 
Pokrzywdzonym jest bowiem jedynie ten, kogo dobro prawne jest bezpośrednio naruszone lub zagrożone przez dane przestępstwo (art. 49 § 1 KPK). Przestępstwo zabójstwa jako chroniące życie człowieka dotknęło bezpośrednio jedynie jego ofiarę, najbliżsi zaś jedynie pośrednio zostali nim dotknięci w zakresie swego zdrowia, w tym i psychiki.

Następnie dodaje także, że „Prawo cywilne, a za nim i karne, nie przewidują — jak dotąd - zadośćuczynienia za krzywdę wyrządzoną przestępną śmiercią określonej osoby osobom jej bliskim"21.

Porównując zakres desygnatów „,pokrzywdzonego" i „ofiary”, można wysnuć następujące wnioski. Po pierwsze, zastosowane w dyrektywie pojęcie „ofiara” $\mathrm{z}$ jednej strony ma zdecydowanie szerszy zakres znaczeniowy, dlatego że obejmuje nie tylko osobę, która bezpośrednio doznała krzywdy, ale też członków jej rodziny. Co więcej, na gruncie dyrektywy bez znaczenia są okoliczności i rodzaj szkody, ponieważ rozumiana jest ona szeroko, w tym jako krzywda fizyczna, psychiczna, moralna i emocjonalna, a także strata majątkowa. Natomiast status pokrzywdzonego w polskiej procedurze karnej przysługuje jedynie osobie, której rodzaj, zakres i okoliczności pokrzywdzenia odpowiadają znamionom danego typu czynu zabronionego. $\mathrm{Z}$ drugiej strony na gruncie dyrektywy status ofiary przysługuje wyłącznie osobie fizycznej, podczas gdy pokrzywdzonym może być również osoba prawna, niemająca osobowości prawnej instytucja państwowa lub samorządowa albo inna jednostka organizacyjna, której odrębne przepisy przyznają zdolność prawną, jak też zakład ubezpieczeń w zakresie, w jakim pokrył szkodę wyrządzoną pokrzywdzonemu przez przestępstwo lub jest zobowiązany do jej pokrycia. Zakresy omawianych pojęć pozostają więc $w$ relacji krzyżowania.

Po drugie, w perspektywie sprawiedliwości naprawczej pozytywnie należy ocenić fakt, że pojęcie „ofiara” obejmuje nie tylko osobę, która bezpośrednio doznała krzywdy, lecz także członków jej rodziny zdefiniowanych w art. 2 ust. 1 lit. b dyrektywy. Godzi się przy tym zauważyć, że zaliczono do nich, poza małżonkiem, krewnymi w linii prostej, rodzeństwem oraz osobami pozostającymi na utrzymaniu ofiary, również „osoby pozostające z ofiarą, w sposób trwały i ciągły, w bliskim pożyciu we wspólnym gospodarstwie domowym". Wydaje się, że takie ujęcie pozwala na zakwalifikowanie do członków rodziny także osób, z którymi ofiara pozostawała w nieformalnych związkach, w tym partnerów, konkubentów, i to bez względu na ich płeć. Negatywnie należałoby zaś ocenić ograniczenie definicji ofiary wyłącznie do kategorii osób fizycznych. Może to wynikać z historii i rozwoju sprawiedliwości naprawczej, której źródeł upatruje się w państwowości i organizacji wymiaru sprawiedliwości ludów pierwotnych, między innymi Maorysów i Aborygenów. Niemniej jednak sprawiedliwość naprawcza, jeśli ma efektywnie funkcjonować w państwach o bardziej złożonej strukturze, musi uwzględniać istnienie osób prawnych i jednostek organizacyjnych, które w ocenie autorki na równi z osobami fizycznymi mogą korzystać z omawianych mechanizmów.

21 Wyrok SN z dnia 23 lipca 2008 roku, sygn. V KK 377/07, Legalis nr 130502. 


\section{Sytuacja prawna pokrzywdzonego w postępowaniu wykonawczym}

Kodeks karny wykonawczy na określenie osoby pokrzywdzonej przestępstwem nie stosuje określenia „ofiara”, lecz „pokrzywdzony”. Nie wprowadza przy tym autonomicznej definicji, zatem na zasadzie art. $1 \S 2$ k.k.w. uprawnione jest odpowiednie stosowanie przepisu art. 49 k.p.k. ${ }^{22}$ Wszystkie poczynione wcześniej uwagi dotyczące pokrzywdzonego będą aktualne również na etapie postępowania wykonawczego. Dodatkowo warto w tym miejscu wyjaśnić, że przepisy kodeksu karnego wykonawczego w żadnym miejscu nie uprawniają organów postępowania wykonawczego do rozstrzygania o uznaniu ofiary za pokrzywdzonego. Oznacza to, że z uprawnień pokrzywdzonych wynikających z kodeksu karnego wykonawczego mogą korzystać wyłącznie ofiary, które uzyskały status pokrzywdzonego (niekoniecznie strony) w toku postępowania karnego.

Przechodząc do omówienia uprawnień pokrzywdzonego w postępowaniu wykonawczym, należy zacząć od stwierdzenia, że materia kodeksowa dotycząca pokrzywdzonego — z przyczyn, o których była mowa na wstępie — jest zdecydowanie węższa niż ta dotycząca skazanego. W przeciwieństwie do skazanego ${ }^{23}$ pokrzywdzony nie jest stroną w postępowaniu wykonawczym toczącym się przed sądem i nie może takiego statusu uzyskać. Co oczywiste, nie jest również organem postępowania wykonawczego ${ }^{24}$. Z tego względu w przypadkach, w których pokrzywdzony będzie realizował swoje kodeksowe uprawnienia, może on zostać co najwyżej określony mianem uczestnika tego postępowania, chociaż kodeks karny wykonawczy nie nazywa go w ten sposób.

Porównując zakres uprawnień przysługujących pokrzywdzonemu w postępowaniu wykonawczym na gruncie kodeksu karnego wykonawczego z 1969 ro$\mathrm{ku}^{25}$ i kodeksu karnego wykonawczego z 1997 roku, zauważymy pewien postęp. Poprzednio obowiązujący kodeks dotykał bowiem uprawnień pokrzywdzonego jedynie w dwóch kwestiach, to jest: co do nawiązki oraz podania wyroku do publicznej wiadomości ${ }^{26}$. Aktualny kodeks zaś rozszerza ten zakres o kilka znaczących uprawnień.

Przede wszystkim należy wskazać uprawnienie pokrzywdzonego do udziału w posiedzeniu sądowym. Dotyczy to jednak wyłącznie przypadków, gdy ustawa tak stanowi. W posiedzeniu sądu wyższej instancji pokrzywdzony może wziąć udział, o ile przysługiwało mu prawo udziału w posiedzeniu przed sądem

22 Wyrok SN z dnia 30 stycznia 2014 roku...

23 Art. $6 \S 1$ k.k.w.

24 A contrario art. 2 k.k.w.

25 Ustawa z dnia 19 kwietnia 1969 roku — Kodeks karny wykonawczy (Dz.U. Nr 13, poz. 98; dalej: k.k.w. z 1969 roku).

${ }^{26}$ Więcej na ten temat zob. W. Sych, Zmiana sytuacji pokrzywdzonego w stadium wykonawczym polskiego procesu karnego, „Prokuratura i Prawo” 2006, nr 2. 
I instancji ${ }^{27}$. Jak już podniesiono, uprawnienie to będzie przysługiwało pokrzywdzonemu niezależnie od tego, czy w postępowaniu jurysdykcyjnym uzyskał status strony. Uwzględniając jednocześnie, że niestawiennictwo pokrzywdzonego nie wstrzymuje rozpoznania sprawy jedynie w wypadku prawidłowego zawiadomienia go o terminie i celu posiedzenia, to na sądzie ciąży obowiązek należytego zawiadomienia pokrzywdzonego o posiedzeniu w wypadkach, gdy ustawa tak stanowi. Rzecz jednak w tym, że kodeks karny wykonawczy w żadnym przepisie nie przewiduje obecności pokrzywdzonego na posiedzeniu sądowym w postępowaniu wykonawczym. Obecność pokrzywdzonego nie jest wymagana na — szczególnie istotnych z punktu widzenia ochrony jego interesów — posiedzeniach $w$ przedmiocie warunkowego zwolnienia ${ }^{28}$ oraz odwołania warunkowego zwolnienia $^{29}$. Z tego względu w doktrynie podnosi się, że charakter bezwzględny ma jedynie obowiązek zawiadomienia prokuratora, skazanego, obrońcy i sądowego kuratora zawodowego w zakresie jego działania ${ }^{30}$. W konsekwencji brakuje podstawy prawnej umożliwiającej pokrzywdzonemu udział w posiedzeniu sądowym w postępowaniu wykonawczym.

Wprawdzie wskazuje się, że jeżeli osoba uprawniona do udziału w posiedzeniu stawi się na nim nawet bez zawiadomienia, to należy umożliwić jej wzięcie udziału w czynności procesowej, niezależnie od jej charakteru ${ }^{31}$. Nie dotyczy to jednak pokrzywdzonego, którego ustawodawca w żadnym przypadku nie uprawnił do udziału w posiedzeniu. Podstawą prawną uczestnictwa pokrzywdzonego w posiedzeniu sądowym nie będzie także przepis art. $22 \S 2$ k.k.w., zgodnie z którym sąd może dopuścić do udziału w posiedzeniu również inne osoby niż wymienione $\mathrm{w} \S 1$ tego przepisu, jeżeli ich udział może mieć znaczenie dla rozstrzygnięcia. O ile przepis ten może być podstawa uczestnictwa $\mathrm{w}$ posiedzeniu przedstawiciela skazanego ${ }^{32}$, o tyle nie będzie dotyczył pokrzywdzonego, który został wymieniony $\mathrm{w} \S 1$ tego przepisu.

Konkludując, trzeba wskazać, że ustawodawca przyznał pokrzywdzonemu iluzoryczne uprawnienie, które w żadnym przypadku nie może zostać zrealizowane $\mathrm{w}$ praktyce. Taki stan rzeczy z oczywistych przyczyn należy ocenić negatywnie. Tym bardziej że sam udział pokrzywdzonego w posiedzeniu nie jest równoznaczny z obowiązkiem uwzględnienia jego opinii, na przykład w kwestii warunkowego zwolnienia lub odwołania warunkowego zwolnienia. Sama obecność pokrzywdzonego raczej nie wpłynęłaby także automatycznie na wydłużenie

\footnotetext{
27 Art. $22 \S 1$ k.k.w.

28 Art. $161 \S 1$ k.k.w.

29 Art. 160 § 6 k.k.w.

30 S. Lelental, Kodeks karny wykonawczy. Komentarz, Warszawa 2020.

31 I. Zgoliński, Komentarz do art. $22 \mathrm{KKW}$, [w:] Kodeks karny wykonawczy. Komentarz, red. J. Lachowski, Warszawa 2018, Legalis.

32 Ibidem.
} 
czy wzrost kosztów postępowania wykonawczego, nawet jeżeli sąd miałby obowiązek należytego zawiadomienia go o terminie i celu posiedzenia.

Następne uprawnienie przysługuje jedynie indywidualnie oznaczonemu pokrzywdzonemu, a mianowicie pokrzywdzonemu małżonkowi skazanego albo pokrzywdzonym osobom, w stosunku do których małżonek skazanego obciążony jest obowiązkiem alimentacyjnym. W takich przypadkach egzekucja kary grzywny, nawiązki i należności sądowych z majątku wspólnego małżonków jest niedopuszczalna ${ }^{33}$. Stanowi to wyjątek od ogólnej zasady, zgodnie z którą jeżeli zaspokojenie tych należności z osobistego majątku skazanego oraz z wynagrodzenia za pracę lub za inne usługi świadczone przez niego osobiście, jak również z praw twórcy wynalazku, wzoru użytkowego oraz projektu racjonalizatorskiego okaże się niemożliwe i zostanie stwierdzone w protokole, to egzekucja może być prowadzona z majątku wspólnego ${ }^{34}$.

W dalszej kolejności warto zwrócić uwagę na funkcjonowanie Funduszu Pomocy Pokrzywdzonym oraz Pomocy Postpenitencjarnej. W tym kontekście pozytywnie trzeba ocenić to, że regulując działanie Funduszu Sprawiedliwości, ustawodawca posługuje się określeniem „osoby pokrzywdzone przestępstwem”, co mając na względzie zasady wykładni literalnej, należy interpretować znacznie szerzej niż termin ,,pokrzywdzony” z art. 49 k.p.k. Taki sposób wykładni nie powinien być w żadnym stopniu podważany, ponieważ o intencji ustawodawcy objęcia pomocą możliwie szerokiej grupy osób dotkniętych przestępstwem świadczy również uwzględnienie osób najbliższych osobom pokrzywdzonym przestępstwem $^{35}$, a nawet świadków przestępstwa i osób im najbliższych ${ }^{36}$.

W kontekście tematu opracowania nie można pominąć także szczególnego uprawnienia wyłącznie dla skazanych pokrzywdzonych. Jeżeli w związku z toczącym się lub zakończonym postępowaniem karnym, w którym skazany uczestniczy lub uczestniczył między innymi w charakterze pokrzywdzonego, wystąpiło poważne zagrożenie lub istnieje bezpośrednia obawa wystąpienia poważnego zagrożenia dla jego życia lub zdrowia, dyrektor zakładu karnego obejmuje takiego skazanego szczególną ochroną w warunkach zwiększonej izolacji i zabezpieczenia, polegającej przede wszystkim na: kontroli stanu jego zdrowia, udzielaniu pomocy psychologicznej, objęciu nadzorem administracji zakładu karnego widzeń skazanych oraz kontroli rozmów w trakcie tych widzeń, stosowaniu cenzury korespondencji oraz kontroli rozmów telefonicznych. Wyłącznie za zgodą skazanego pokrzywdzonego szczególna ochrona może polegać na stosowaniu wobec niego warunków, w których karę odbywają tak zwani osadzeni niebezpieczni, albo warunków ochrony osobistej w rozumieniu ustawy z dnia 25 czerwca 1997 ro-

\footnotetext{
33 Art. 28 § 2 k.k.w.

34 Art. $28 \S 1$ k.k.w.

35 Art. $43 \S 8$ pkt 1 k.k.w.

36 Art. $43 \S 8$ pkt 2a k.k.w.
} 
ku o świadku koronnym ${ }^{37}$. Tożsame uprawnienie przysługuje w takich okolicznościach pokrzywdzonym tymczasowo aresztowanym ${ }^{38}$.

Jednym $\mathrm{z}$ najistotniejszym uprawnień przysługujących pokrzywdzonemu w postępowaniu wykonawczym jest jednak prawo do bycia informowanym o sytuacjach związanych z opuszczeniem przez skazanego zakładu karnego ${ }^{39}$. Zostało ono uregulowane w oddziale 13 kodeksu karnego wykonawczego, obejmującym wyłącznie art. 168a dodany ustawą z dnia 16 kwietnia 2004 roku o zmianie ustawy - Kodeks karny oraz niektórych innych ustaw ${ }^{40}$. Przepis ten uprawnia pokrzywdzonego do złożenia wniosku, który obliguje sędziego penitencjarnego lub dyrektora zakładu karnego do niezwłocznego zawiadomienia pokrzywdzonego (jego przedstawiciela ustawowego lub osoby, pod której stałą pieczą pozostaje) o zwolnieniu skazanego z zakładu karnego po odbyciu kary, o ucieczce z zakładu karnego, a także o wydaniu decyzji o udzieleniu: przepustek, o których mowa w art. 91 pkt 7 k.k.w. i art. 92 pkt 9 k.k.w., czasowego zezwolenia na opuszczenie zakładu karnego bez dozoru lub bez konwoju funkcjonariusza Służby Więziennej albo asysty innej osoby godnej zaufania, o których mowa w art. $138 \S 1$ pkt 7 lub 8 k.k.w., art. 141a $\S 1$ k.k.w., art. $165 \S 2$ k.k.w. oraz art. $234 \S 2$ k.k.w., przerwy w wykonaniu kary i warunkowego zwolnienia. Dyspozycja przepisu obejmuje więc zarówno przypadki legalnego opuszczenia przez skazanego jednostki penitencjarnej o charakterze tymczasowym oraz stałym, jak i przypadki bezprawnego samouwolnienia. Pokrzywdzony, o ile złożył wniosek, o którym mowa w art. 168a k.k.w., jest także niezwłocznie zawiadamiany o wydaniu postanowienia w przedmiocie zezwolenia skazanemu na odbywanie kary pozbawienia wolności w systemie dozoru elektronicznego ${ }^{41}$.

Omawiane uprawnienie przysługuje pokrzywdzonemu wyłącznie na jego wniosek, dlatego też sąd I instancji, kierując orzeczenie do wykonania, obowiązany jest pouczyć pokrzywdzonego o prawie do złożenia takiego dokumentu ${ }^{42}$. Ustawodawca nie precyzuje przy tym, w jakiej formie winno zostać ono udzielone. W praktyce przyjmuje ono formę pisma skierowanego do pokrzywdzonego, które najczęściej ogranicza się do przytoczenia treści przepisu art. 168a k.k.w. W tym kontekście Wojciech Sych słusznie zaleca, że pismo takie należałoby opatrzyć zwięzłym i zrozumiałym komentarzem oraz informacją, że dane osobowe $i$ adresowe nie zostana udostępnione skazanemu. W ten sposób wykluczono by możliwość nieskorzystania przez pokrzywdzonego z tego uprawnienia z powodu

37 Art. 88d k.k.w.

38 Art. 212 ba k.k.w.

39 Więcej na ten temat zob. A. Kwieciński, Obowiąek informowania pokrzywdzonego o opuszczeniu przez skazanego zaktadu karnego - uwagi na tle stosowania art. 168 a k.k.w., „Nowa Kodyfikacja Prawa Karnego" 27, 2011; M. Klejnowska, Informowanie pokrzywdzonego o zwolnieniu oskarżonego (skazanego) z aresztu (zakładu karnego), „Przegląd Sądowy” 2005, nr 1.

40 Dz.U. Nr 93, poz. 889.

41 Art. 43lh $\S 5$ k.k.w.

42 Art. 168a § 2 k.k.w. 
obawy przed ponownym zagrożeniem ze strony skazanego ${ }^{43}$. Pozytywnie należy ocenić to, że ustawodawca nie wprowadza żadnych wymogów proceduralnych ani ograniczeń temporalnych limitujących możliwość złożenia przez pokrzywdzonego omawianego wniosku. Trafny jest więc pogląd, zgodnie z którym może on zostać złożony w każdym czasie aż do zakończenia wykonywania kary przez skazanego ${ }^{44}$. Z kolei, gdy idzie o początkowy moment, od którego taki wniosek mógłby zostać skutecznie złożony, ratio legis omawianego przepisu nakazywało przyznanie pokrzywdzonemu tego uprawnienia na każdym etapie postępowania karnego, a więc jeszcze przed formalnym wszczęciem postępowania wykonawczego. Wydaje się, że nic nie stoi na przeszkodzie, by pokrzywdzony złożył taki wniosek do akt postępowania jeszcze na etapie postępowania przygotowawczego, na przykład w przypadku tymczasowego aresztowania lub na wypadek wydania wyroku skazującego na karę pozbawienia wolności.

Pogląd ten jest o tyle uzasadniony, że art. $11 \S 1$ a k.k.w. zobowiązuje sąd do przesłania wniosku pokrzywdzonego także dyrektorowi aresztu śledczego. W związku z tym słusznie podnosi Stefan Lelental, że art. 168a $\S 2$ k.k.w. nie można odczytywać w ten sposób, że obowiązek pouczenia pokrzywdzonego spoczywa na sądzie dopiero w chwili kierowania orzeczenia do wykonania, choć wynikałoby to $z$ literalnej wykładni tego przepisu. Badacz postuluje zastąpienie sformułowania „sąd, kierując” zwrotem „sąd, który kieruje"45, ponieważ potrzeba oraz możliwość pouczenia pokrzywdzonego o tym uprawnieniu w praktyce może wystąpić znacznie wcześniej. Ponadto wypadałoby opowiedzieć się za możliwością złożenia wniosku nie tylko do sądu kierującego orzeczenie do wykonania, ale też do organów zobowiązanych do informowania pokrzywdzonego, w szczególności dyrektora zakładu karnego lub aresztu śledczego oraz sędziego penitencjarnego ${ }^{46}$, choć w praktyce najczęściej wniosek będzie składany do sądu I instancji w odpowiedzi na otrzymane pouczenie.

W tym zakresie Tomasz Kalisz proponuje rozwiązanie porządkujące istniejącą praktykę, a mianowicie - aby wszystkie wnioski składane do innych niż sąd I instancji organów były uznane za skuteczne, a jednocześnie zostały niezwłocznie przekazane do tego sądu. Wówczas sąd I instancji, kierując orzeczenie do wykonania, będzie zobligowany przekazać właściwą wiadomość organom bezpośrednio zobowiązanym do zawiadomienia pokrzywdzonego ${ }^{47}$. Dotyczy to w równym stopniu wniosku złożonego na piśmie, jak też ustnie, który to powinien zostać utrwalony w formie pisemnego protokołu. Dobrym rozwiązaniem byłoby również dołączanie do wspomnianego pisemnego zawiadomienia formularza lub

43 W. Sych, op. cit., s. 144.

44 Ibidem.

45 S. Lelental, op. cit.

46 W. Sych, op. cit., s. 145.

47 T. Kalisz, Sędziowski nadzór penitencjarny. Polski model nadzoru i kontroli nad legalnościa i prawidlowościa wykonywania środków o charakterze izolacyjnym, Wrocław 2010, s. 197. 
wzoru wniosku z art. 168a k.k.w., który pokrzywdzony mógłby uzupełnić swoimi danymi, co niewątpliwie usprawniłoby oraz ujednoliciło zakres i formę pozyskiwanych informacji.

W przypadku wystąpienia przez pokrzywdzonego z omawianym wnioskiem sąd przesyła go dyrektorowi zakładu karnego lub aresztu śledczego wraz z danymi zawierającymi imię, nazwisko oraz adres pokrzywdzonego ${ }^{48}$. Z praktycznego punktu widzenia warto rozważyć poszerzenie katalogu tych danych o numer telefonu i adres poczty elektronicznej pokrzywdzonego. Powszechne korzystanie z tych środków komunikacji niewątpliwe usprawniłoby wymianę informacji między administracją zakładu karnego a pokrzywdzonym. Jest to o tyle istotne, że aby omawiana regulacja spełniała swoje cele, pokrzywdzony powinien być niemal natychmiast zawiadamiany o opuszczeniu zakładu karnego przez skazanego lub jego samowolnym uwolnieniu. W ten sposób ograniczone zostałyby także wydatki związane z wysyłaniem tradycyjnej korespondencji ${ }^{49}$.

Nie bez znaczenia wydaje się również zakres wiadomości przekazywanych przez sędziego penitencjarnego lub dyrektora zakładu karnego i aresztu śledczego. Pokrzywdzony powinien niezwłocznie otrzymywać zrozumiałą informację, która pozwalałaby na psychiczne i emocjonalne przygotowanie się na możliwe spotkanie ze skazanym na wolności, a w skrajnych przypadkach podjęcie w tym czasie stosownych środków ostrożności. $\mathrm{Z}$ punktu widzenia ratio legis omawianego przepisu pokrzywdzony winien być informowany nie tylko o zajściu wskazanych zdarzeń, ale też - w zależności od ich rodzaju - o planowanym czasie trwania i regulaminowym powrocie skazanego do jednostki penitencjarnej, a w przypadku ucieczki skazanego - o jego ujęciu. Pozwoliłoby to na ograniczenie czasu trwania niepewności i stresu związanego z przebywaniem skazanego na wolności, tym bardziej, jeżeli jest ono nielegalne.

Uzupełniająco należy wskazać, że w zasadzie tożsame uprawnienie przysługuje pokrzywdzonemu w przypadku orzeczenia wobec sprawcy środka zabezpieczającego w formie pobytu w zakładzie psychiatrycznym ${ }^{50}$. Na wniosek pokrzywdzonego upoważniony sędzia niezwłocznie zawiadamia go (jego przedstawiciela ustawowego lub osobę, pod której stałą pieczą pozostaje) o zwolnieniu sprawcy z zakładu psychiatrycznego po uchyleniu lub zmianie środka zabezpieczającego, ucieczce sprawcy z zakładu psychiatrycznego, a także o udzieleniu zezwolenia na czasowy pobyt poza zakładem.

W obu wypadkach ustawodawca stanowi, że w uzasadnionych przypadkach zawiadomienie przekazuje się również świadkowi ${ }^{51}$. Nie wyjaśnia jednak, jakie przypadki uzasadniają skierowanie takiego zawiadomienia także do świadka. Wydaje się, że może to dotyczyć okoliczności, o których mowa w art. 88d k.k.w.,

48 Art. $11 \S 1$ a k.k.w.

49 W. Sych, op. cit.

50 Art. 205a k.k.w.

51 Art. 168a $\S 6$ oraz art. 205a $\S 3$ k.k.w. 
a więc gdy w związku z toczącym się lub zakończonym postępowaniem karnym, w którym świadek uczestniczył, występuje poważne zagrożenie lub istnieje bezpośrednia obawa wystąpienia poważnego zagrożenia dla jego życia lub zdrowia. Tezę tę uzasadnia fakt, że art. 88d k.k.w. oprócz pokrzywdzonego skazanego (odpowiednio tymczasowo aresztowanego pokrzywdzonego) dotyczy także skazanego świadka. Wątpliwości budzi jednak, czy w takich — bezsprzecznie uzasadnionych - przypadkach organ zawiadamiający nie powinien podjąć dalej idących środków mających na celu ochronę świadka aniżeli samo zawiadomienie. Wątpliwości tych dotychczas ani doktryna, ani orzecznictwo nie rozstrzygnęło z uwagi na ograniczony zakres takich sytuacji. Brakuje również jawnych statystyk, które obrazowałyby, czy omawiane uprawnienie było w ogóle w praktyce stosowane, w związku z czym dywagacje w tej kwestii mają raczej charakter teoretyczny.

Przechodząc do omówienia dalszych uprawnień pokrzywdzonego, należy nadmienić, że $w$ razie orzeczenia obowiązku naprawienia szkody lub zadośćuczynienia na rzecz osoby, która nie brała udziału w sprawie, nawiązki lub świadczenia pieniężnego, sąd - z urzędu i bez pobierania jakichkolwiek opłat — przesyła tytuł egzekucyjny pokrzywdzonemu lub innej osobie uprawnionej ${ }^{52}$. Regulację tę trzeba ocenić pozytywnie, zwłaszcza z perspektywy sprawiedliwości naprawczej i wspomnianych na wstępie celów wykonywania kary pozbawienia wolności, ponieważ może ona zainicjować oraz zdecydowanie ułatwić proces dochodzenia przez pokrzywdzonego zasądzonych świadczeń.

Na koniec trzeba wskazać na uprawnienie pokrzywdzonego, choćby nie był stroną postępowania karnego, do złożenia zażalenia na postanowienie w przedmiocie sposobu podania wyroku do publicznej wiadomości ${ }^{53}$. Warto nadmienić, że tożsame uprawnienie przysługiwało pokrzywdzonemu na podstawie art. 186 k.k.w. z 1969 roku.

\section{Podsumowanie - uprawnienia ofiary w perspektywie sprawiedliwości naprawczej}

Podsumowując uprawnienia pokrzywdzonego w postępowaniu wykonawczym, należy odnieść je do standardu, jaki w polityce kryminalnej wprowadza obecnie sprawiedliwość naprawcza. Proponuje ona nie tylko narzędzia umożliwiające ofierze przestępstwa udział w szeroko rozumianym postępowaniu karnym, ale tworzy też standard uczestnictwa społeczności lokalnej w tej procedurze, znacząco przyczyniając się w ten sposób do zwiększenia przenikalności jednostek penitencjarnych.

\footnotetext{
52 Art. 196 k.k.w.
}

53 Art. 197 k.k.w. 
W tym kontekście na początku trzeba zauważyć, że już posłużenie się przez ustawodawcę w kodeksie karnym wykonawczym terminem ,pokrzywdzony” zamiast „ofiara” zdecydowanie ogranicza uprawnienia tej osoby względem tego, co proponują twórcy rekomendacji. Pomijając nawet kwestie terminologii, zakres uprawnień przysługujących pokrzywdzonemu w postępowaniu wykonawczym jest zdecydowanie zbyt wąski, gdy weźmiemy pod uwagę, że prawodawca europejski za uzasadnione uznaje, aby „ofiary przestępstw miały więcej do powiedzenia w kwestii wiktymizacji, porozumienia ze sprawcą przestępstwa, otrzymania zadośćuczynienia oraz osiągnięcia zadowolenia z przebiegu postępowania". W zasadzie jedynym rzeczywistym uprawnieniem pokrzywdzonego, pozwalającym mu na wykazanie jakiejkolwiek aktywności w postępowaniu wykonawczym, jest prawo złożenia wniosku, o którym mowa w art. 168a k.k.w. Niestety dotychczas nie przeprowadzono rzetelnych badań empirycznych, które stwierdzałyby, w jakim stopniu pokrzywdzeni korzystają z tego uprawnienia oraz czy posiadają o nim odpowiednią wiedzę. Nie mamy również informacji, w jaki sposób pod względem jakościowym obowiązek z art. 168a k.k.w. jest wykonywany w praktyce. Niemniej omawiane uprawnienie jest bardzo wartościowym instrumentem z punktu widzenia ochrony interesu pokrzywdzonego w postępowaniu wykonawczym. Natomiast absolutnie negatywnie należy ocenić to, że prawo pokrzywdzonego do udziału w posiedzeniach sądowych istnieje wyłącznie w teorii. Ustawodawca nie tylko bowiem pozbawia $\mathrm{w}$ ten sposób pokrzywdzonego prawa do wypowiedzenia się $\mathrm{w}$ kwestiach istotnych $\mathrm{z}$ jego punktu widzenia, lecz także wyłącza jego jakiekolwiek uczestnictwo w tych postępowaniach. W aktualnym stanie rzeczy nie ma więc mowy o jakimkolwiek dialogu (bezpośrednim lub pośrednim) między ofiarą a sprawcą przestępstwa. Nie mówiąc nawet o włączeniu w ten dialog innych osób bezpośrednio lub pośrednio dotkniętych przez przestępstwo, jakby sobie tego życzył prawodawca europejski w rekomendacji.

Sytuacja ofiary w postępowaniu wykonawczym w perspektywie sprawiedliwości naprawczej przedstawia się jeszcze gorzej, gdy uwzględnimy, że jej istoty należy upatrywać w takich mechanizmach, jak mediacje między ofiarą a sprawcą przestępstwa, mediacje karne, konferencje sprawiedliwości naprawczej, grupowe konferencje rodzinne, kręgi orzekające lub kręgi mediacyjne. Wprawdzie sąd penitencjarny, orzekając o warunkowym zwolnieniu skazanego, uwzględnia ugodę zawartą w wyniku mediacji ${ }^{54}$, jednak trudności związane z wykładnią i zastosowaniem tego przepisu, zwłaszcza brak przepisów proceduralnych dotyczących mediacji w kodeksie karnym wykonawczym ani jednoznacznego odesłania do

54 Art. $162 \S 1$ k.k.w. 
przepisów kodeksu postępowania karnego w tym zakresie, powoduje, że de facto mediacja w postępowaniu wykonawczym najpewniej nie istnieje ${ }^{55}$.

Zakres uprawnień pokrzywdzonego w postępowaniu wykonawczym oceniany z perspektywy sprawiedliwości naprawczej, uwzględniając w szczególności rekomendację, należy ocenić negatywnie. Ustawodawca krajowy dotychczas nie zapewnił bowiem pokrzywdzonemu podstawowych uprawnień, jak na przykład prawo do uczestniczenia w posiedzeniu sądowym czy prawo do zainicjowania mediacji ze sprawcą. Problemem jest również brak w polskim postępowaniu karnym, na każdym jego etapie, podstawowych mechanizmów sprawiedliwości naprawczej, takich jak wspomniane mediacje, konferencje sprawiedliwości naprawczej czy kręgi mediacyjne. Najistotniejsze jest jednak to, że przepisy prawa karnego wykonawczego nie stwarzają nawet podstaw prawnych, które umożliwiałyby wdrożenie tych instrumentów, choćby na próbę, do postępowania wykonawczego w celu zweryfikowania, czy w praktyce przyniosłyby pozytywne rezultaty. Konsekwencją takiego stanu rzeczy jest to, że projekty sprawiedliwości naprawczej - z powodzeniem realizowane na świecie - dotychczas nie były wdrażane w polskich jednostkach penitencjarnych ${ }^{56}$. Niewątpliwie wpływa to negatywnie przede wszystkim na interes pokrzywdzonego, lecz także sprzyja bierności skazanych w zakresie realizacji obowiązków kompensacyjnych.

Na koniec, dokonując oceny opisanego stanu rzeczy z nieco szerszej, zakreślonej na wstępie artykułu perspektywy, należy zgodzić się, że mechanizmy służące aktywizacji pokrzywdzonego oraz angażowaniu społeczności lokalnej w postępowanie wykonawcze prowadzą do zwiększenia przenikalności jednostek penitencjarnych oraz łagodzą niektóre negatywne konsekwencje izolacji penitencjarnej. Wdrażanie narzędzi sprawiedliwości naprawczej w postępowaniu wykonawczym może skutecznie niwelować barierę istniejącą między przestrzenią jednostki penitencjarnej a środowiskiem zewnętrznym, minimalizując, a niekiedy eliminując efekt dyskulturacji. Rezygnacja $\mathrm{z}$ wdrożenia oferty sprawiedliwości naprawczej w postępowaniu wykonawczym, przede wszystkim zaniechanie zwiększenia roli oraz aktywności pokrzywdzonego i społeczności lokalnej w tym procesie, prowadzi jedynie do spotęgowania stopnia totalizacji jednostek penitencjarnych.

55 Zob. m.in. D. Michta, A. Szczepański, Mediacja w postępowaniu wykonawczym, „Palestra” 2013, nr 7-8; E. Zielińska, J. Klimczak, Zakres stosowania mediacji w sprawach karnych w praktyce wymiaru sprawiedliwości, Warszawa 2020.

56 Dla porównania: najbardziej rozpowszechniony program Sycamore Tree był realizowany w następujących państwach europejskich: Niemcy, Szkocja, Północna Irlandia, Holandia, Włochy, Węgry. Inny projekt kierowany przez Prison Fellowships - Communities of Restoration (APAC) przeprowadzany był w zakładach karnych w Bułgarii, Łotwie, Niemczech oraz na Węgrzech. Natomiast Alternatives to Violence Project (AVP) został zrealizowany w 2011 roku w 56 krajach, w tym Białorusi, Ukrainie, Chorwacji, Niemczech, Litwie, Holandii oraz Rosji. 


\section{Bibliografia}

\section{Literatura}

Bieńkowska E., Ofiary przestępstw w postępowaniu karnym - nowe standardy Unii Europejskiej, „Państwo i Prawo” 2014, nr 4.

Bieńkowska E., Pokrzywdzony w świetle najnowszych nowelizacji przepisów prawa karnego, „Prokuratura i Prawo" 2014, nr 3.

Bieńkowska E., Uprawnienia pokrzywdzonego w ujęciu nowych projektów nowelizacji prawa karnego, „Prokuratura i Prawo” 2014, nr 11-12.

Christie N., Conflicts as Property, „The British Journal of Criminology” 17, 1977, nr 1.

Cieślak M., Polska procedura karna, Warszawa 1971.

Consedine J., Sprawiedliwość naprawcza. Przywrócenie ładu społecznego, Warszawa 2004.

Dudka K., Artymiak G., Sytuacja pokrzywdzonego w procesie karnym ze szczególnym uwzględnieniem roli oskarżyciela positkowego i powoda cywilnego, Warszawa 2012.

Goffman E., Asylums. Essays on the Social Situation of Mental Patients and Other Inmates, Garden City 1961.

Goffman E., Instytucje totalne. O pacjentach szpitali psychiatrycznych i mieszkańcach innych instytucji totalnych, Sopot 2011.

Janusz-Pohl B., Zasada udziału czynnika społecznego, [w:] System prawa karnego procesowego. Zasady procesu karnego, red. P. Wiliński, Warszawa 2014.

Kalisz T., Sędziowski nadzór penitencjarny. Polski model nadzoru i kontroli nad legalnościa i prawidłowościa wykonywania środków o charakterze izolacyjnym, Wrocław 2010.

Kalisz T., Kwieciński A., Cele izolacji penitencjarnej w perspektywie odrzucenia idei przymusowej resocjalizacji, „Przegląd Prawa i Administracji” 95, 2013.

Klejnowska M., Informowanie pokrzywdzonego o zwolnieniu oskarżonego (skazanego) z aresztu (zaktadu karnego), „Przegląd Sądowy” 2005, nr 1.

Kwieciński A., Obowiąek informowania pokrzywdzonego o opuszczeniu przez skazanego zakładu karnego - uwagi na tle stosowania art. 168 a k.k.w., „Nowa Kodyfikacja Prawa Karnego” 27, 2011.

Lelental S., Kodeks karny wykonawczy. Komentarz, Warszawa 2020.

Llewellyn J., Howse R., Restorative Justice - A Conceptual Framework, [Ottawa] 1998.

Łapińska K., Mańczuk M., Udziat społeczeństwa w polskim postępowaniu wykonawczym $z$ uwzględnieniem wybranych regulacji państw europejskich, „Białostockie Studia Prawnicze” 2016, z. 21.

Michta D., Szczepański A., Mediacja w postępowaniu wykonawczym, „Palestra” 2013, nr 7-8.

Młynarczyk Z., Udziat czynnika społecznego w postepowaniu karnym wykonawczym, „Ruch Prawniczy, Ekonomiczny i Socjologiczny" 1979, nr 3.

Pokrzywdzony jako uczestnik postępowań represyjnych. Czwarty wierzchołek trójkąta?, red. P. Czernecki, A. Światłowski, Warszawa 2021.

Posłuszny Ł., Instytucje totalne dzisiaj: stan badań, krytyka, rekonfiguracje, „Studia Socjologiczne" 4 (227), 2017.

Sommer R., Patients Who Grow Old in a Mental Hospital, „Geriatrics” 14, 1959.

Sych W., Zmiana sytuacji pokrzywdzonego w stadium wykonawczym polskiego procesu karnego, „Prokuratura i Prawo” 2006, nr 2.

Wieczorek K., Udział czynnika społecznego $w$ orzekaniu $w$ polskim i amerykańskim procesie karnym, Szczecin 2012. 
Zgoliński I., Komentarz do art. 22 KKW, [w:] Kodeks karny wykonawczy. Komentarz, red. J. Lachowski, Warszawa 2018.

Zielińska E., Klimczak J., Zakres stosowania mediacji w sprawach karnych w praktyce wymiaru sprawiedliwości, Warszawa 2020.

\section{Akty normatywne}

Ustawa z dnia 19 kwietnia 1969 roku — Kodeks karny wykonawczy (Dz.U. Nr 13, poz. 98).

Ustawa z dnia 6 czerwca 1997 roku - Kodeks karny wykonawczy (tekst jedn. Dz.U. z 2021 r. poz. 53).

Ustawa z dnia 6 czerwca 1997 roku — Kodeks postępowania karnego (tekst jedn. Dz.U. z 2021 r. poz. 534).

Ustawa z dnia 16 kwietnia 2004 roku o zmianie ustawy - Kodeks karny oraz niektórych innych ustaw (Dz.U. Nr 93, poz. 889).

\section{Orzecznictwo}

Uchwała SN z dnia 15 września 1999 roku, sygn. I KZP 26/99, Legalis nr 44490.

Uchwała SN z dnia 21 grudnia 1999 roku, sygn. I KZP 43/99, Legalis nr 45347.

Wyrok SN z dnia 23 lipca 2008 roku, sygn. V KK 377/07, Legalis nr 130502.

Wyrok SN z dnia 17 lutego 2010 roku, sygn. III K 292/09, Legalis nr 364370.

Wyrok SN z dnia 30 stycznia 2014 roku, sygn. III KK 349/13, Legalis nr 776837. 